\title{
HUBUNGAN SIKAP DAN GAYA BELAJAR SISWA TERHADAP KEMAMPUAN MENULIS DESKRIPTIF BAHASA INGGRIS
}

\author{
Honayapto, Herlina ${ }^{1}$ \\ Universitas Negeri Jakarta, Program Pascasarjana S2 \\ JL. Rawamangun Muka, Jakarta Timur, DKI Jakarta 13220 \\ honayapto@yahoo.co.id
}

\begin{abstract}
The objective of this research was to determine whether there are any relationship between students' attitude, students' learning style, and both students' attitude and students' learning style toward the competence of writing English. The research was conducted at Senior High School, class 2, at SMAN. 2 Kambowa, Southeast Sulawesi, and used random sampling with 30 students. The research used correlational quantitative method with descriptive and inferential analysis technique to see correlation between variables. The research results were (1) There is a positive correlation between students' attitude toward the competence of writing English with correlation coefficient 0,95. (2) There is a positive correlation between students' learning style toward the competence of writing English with correlation coefficient 0,86, and (3) There is a positive correlation between students' attitude and learning style toward the competence of writing English with a double correlation coefficient 0.95 . The result of the research concludes that there is a positive correlation between students' attitude and learning style either individually or together to the the competence of writing English.
\end{abstract}

Keywords: Students' attitude, Students' learning style, and Competence of writing English.

\begin{abstract}
Abstrak
Tujuan dari penelitian ini adalah untuk melihat ada atau tidak adanya hubungan antara sikap siswa, gaya belajar siswa, dan atau sikap dan gaya belajar siswa terhadap kemampuan menulis deskriptif bahasa Inggris. Penelitian ini dilakukan di Sekolah Menengah Atas, kelas 2 SMAN. 2 Kambowa, Sulawesi Tenggara dengan menggunakan sampel acak pada 30 siswa. Penelitian ini menggunakan metode kuantitatif korelasional dengan teknik deskriptif dan analisis statistik inferensial untuk melihat korelasi di antara tiap variabel. Hasil penelitian menunjukkan (1) ada korelasi yang positif antara sikap siswa terhadap kemampuan menulis bahasa Inggris dengan koefisien korelasi 0,95. (2) ada
\end{abstract}

\footnotetext{
${ }^{1}$ Pembimbing
} 
korelasi yang positif antara gaya belajar siswa terhadap kemampuan menulis bahasa Inggris dengan koefisien korelasi 0,86 , dan (3) ada korelasi yang positif antara sikap siswa dan gaya belajar siswa terhadap kemampuan menulis bahasa Inggris dengan koefisien korelasi ganda 0,95. Hasil penelitian menyimpulkan bahwa terdapat korelasi yang positif antara sikap siswa dan gaya belajar siswa terhadap kemampuan menulis bahasa Inggris baik sendiri maupun bersamasama.

Kata kunci: Sikap siswa, Gaya belajar siswa, dan Kemampuan menulis bahasa Inggris.

\section{PENDAHULUAN}

Perkembangan sains, tekhnologi, dan ilmu pengetahuan yang begitu pesat di era globalisasi saat ini, membawa banyak perubahan dalam berbagai aspek kehidupan bermasyarakat.Perubahan tersebut mencakup pendidikan, sains, perdagangan, politik, wisata dan berbagai hal menarik lainnya (Julian Edge, 1993: 25). Perubahan yang terjadi tidak terbatas hanya dalam skala nasional, namun muncul pula pada level internasional. Sehingga, tuntutan terhadap penguasaan komunikasi internasional menjadi sangat diperlukan guna menunjang berbagai manfaat atas interaksi sosial bermasyarakat tersebut. Adapun tuntutan penguasaan terhadap komunikasi internasional yang dimaksud salah satunya adalah bahasa Inggris (Musril Zahari, 2011: 12), bahasa Inggris telah menjadi bahasa yang digunakan negaranegara di dunia untuk berkomunikasi satu dengan yang lainnya.

Menyadari hal tersebut, Indonesia telah memuat bahasa Inggris sebagai salah satu mata pelajaran yang mulai diajarkan sejak usia sekolah dasar (SD) (Musril Zahari, 2011: 178) sampai dengan perguruan tinggi (PT). Artinya, bahasa Inggris telah menjadi satu dari sekian banyaknya pelajaran yang diajarkan guru, dan diharapkan dapat menghasilkan atau memperoleh peserta didik yang terampil berbahasa Inggris guna menghadapi tantangan era globalisasi. Dengan demikian, asumsi bahwa peserta didik sudah memiliki kemampuan berbahasa Inggris tidak perlu dipertanyakan lagi.

Akan tetapi, berdasarkan hasil observasi yang dilakukan peneliti selama menjadi guru di Sekolah Menengah Atas Negeri (SMAN) 2 Kambowa pada kelas XI di kabupaten Buton Utara, kemampuan berbahasa Inggris masih sangat kurang, khususnya dalam kemampuan menulis. Padahal, untuk dapat dikatakan terampil atau bangsa yang terpelajar (Tarigan, 2008:4). Kurangnya pada kemampuan menulis tersebut bahkan sampai terbawa pada jenjang perguruan tinggi, menurut Sutanto (2013:6) kurangnya kemampuan menulis diakibatkan sebagai berikut; tidak adanya gagasan untuk berbahasa, seseorang harus mampu menyimak, berbicara, membaca, dan menulis dengan baik (Tarigan, 2008: 1).

Peneliti berfokus pada kemampuan menulis siswa khususnya menulis deskriptif yang masih kurang pada jenjang kelas XI. Sebab, tuntutan terhadap penguasaan 
kemampuan menulis salah satunya menulis deskriptif bahasa Inggris secara eksplisit jelas dinyatakan dalam standar kompetensi dan kompetensi dasar (SK \& KD) mata pelajaran bahasa tersebut. Menulis memang dianggap sebagai salah satu kemampuan berbahasa yang cukup kompleks dibanding tiga keterampilan berbahasa lainnya (Yudi C. \& Widiati U.,2011: 69), tidak berlebihan jika menulis dianggap mencerminkan orang ditulis $(36,6 \%)$, tidak percaya diri dalam tata bahasa $(20,3 \%)$, sulit menyusun gagasan $(19,1 \%)$, kosakata yang terbatas $(16,1 \%)$, dan tidak ada motivasi menulis $(7,9 \%)$.

Selain apa yang dipaparkan Sutanto, kemampuan peserta didik bisa saja dipengaruhi oleh lingkungan eksternal dan internal peserta didik, dalam lingkungan eksternal kurangnya kemampuan berbahasa ini bisa diakibatkan lingkungan belajar yang tidak mendukung, misalnya kurangnya pengetahuan berbahasa Inggris di lingkungan keluarga, sarana dan prasarana pembelajaran yang kurang lengkap, tenaga pendidik yang kurang kompeten, dan diskusi yang tidak komprehensif dengan teman. Sedangkan di lingkungan internal kemampuan berbahasa Inggris bisa diakibatkan faktor pribadi siswa yang berkaitan dengan sikap dan gaya belajar peserta didik.

Sikap dan gaya belajar peserta didik menjadi variabel yang menarik untuk diteliti terkait dengan kemampuan berbahasa khususnya kemampuan menulis deskriptif bahasa Inggris. Sebab, dalam proses belajar-mengajar, peserta didik diharapkan menjadi outcome dari proses pendidikan yang dilakukan. Peserta didik sebagai individu memiliki peran yang penting dalam kesuksesan pembelajaran tersebut. Dengan kata lain, jika seorang peserta didik memiliki antuasiasme belajar yang tinggi dengan ditunjukan dengan sikap positif dan mampu mengenali gaya belajarnya dapat dimanfaatkan untuk kesuksesan belajar, khususnya dalam menulis deskriptif bahasa Inggris.

Sikap merupakan kesiapan atau kecenderungan seseorang untuk bertindak dalam menghadapi suatu objek atau situasi tertentu.(Herlen dalam Djaali, 2008:114), sikap ditunjukkan seseorang ketika menghadapi sesuatu. Jika seseorang memiliki sikap positif terhadap suatu bahasa maka hal tersebut akan membantu memudahkan dalam mempelajari bahasa tersebut (Julian Edge, 1993: 26). Pendapat lain menyebutkan faktor lain yang mempengaruhi hasil belajar siswa adalah sikap (Slameto, 2008:188). Dengan kata lain jika sikap negatif yang ditunjukan siswa, tentu hal ini akan menghambat kesuksesan dalam belajar bahasa. Oleh karena itu, dapat dipahami bahwa sikap terhadap kemampuan menulis deskriptif bahasa Inggris adalah kecenderungan siswa memberikan respon terhadap mata pelajaran bahasa Inggris, terutama aspek menulis deskriptif. Respon yang ditunjukkan mencakup konsep berpikir positif atau negatif, perasaan senang atau tidak senang dan tindakan nyata yang dilakukan terhadap mata pelajaran bahasa Inggris, khususnya pada menulis deskriptif bahasa Inggris. 
Sedangkan gaya belajar adalah cara yang lebih disukai dalam melakukan kegiatan berpikir, memproses, dan mengerti suatu informasi (Derek \& Sue, 2005:89), artinya dengan memahami gaya belajar seseorang memiliki kesempatan besar untuk mengerti tentang satu pembelajaran yang diajarkan. Pendapat lain menyatakan gaya belajar menjadi satu faktor pokok didalam mendapatkan efektifitas belajar (Ghufron \& Rini, 2014:40 ). Dengan demikian konstruksi pemahaman yang terbangun terkait gaya belajar adalah merupakan sebuah kecenderungan pembelajaran yang khusus yang ditunjukkan oleh satu pribadi individu yang berbeda dengan pribadi individu lainnya. Sehingga dalam menghadapi suatu tujuan pembelajaran yang diharapkan, seperti kemampuan dalam menulis deksriptif bahasa Inggris dapat diwujudkan dengan orientasi pada keberhasilan dengan suatu kecenderungan pembelajaran yang konsisten.

Dari apa yang dipaparkan di atas maka dapat diperoleh informasi yang sangat jelas bahwa sikap dan gaya belajar merupakan faktor internal atau faktor yang khas dari seorang peserta didik yang dianggap turut andil menjadi faktor penentu dalam keberhasilan pengajaran bahasa yang dilakukan guru.

Dengan demikian maka peran sikap dan gaya belajar yang dianggap menjadi faktor penting keberhasilan belajar bahasa khususnya dalam kemampuan menulis deskriptif bahasa Inggris bahasa menjadi menarik untuk dipahami. Hal inilah yang kemudian, menjadi landasan menarik bagi peneliti untuk menyelidiki hubungan antara sikap dan gaya belajar siswa terhadap kemampuan menulis deskriptif bahasa Inggris.

\section{METODE PENELITIAN}

Penelitian ini didesain sebagai penelitian kuantitatif asosiatif bermodel deskriptif korelasi multipel. Deskriptif karena berusaha memperoleh informasi berkenaan dengan fenomena yang diamati saat ini. Adapun sebagai model penelitian korelasi multipel, penelitian ini berupaya menjelaskan ada-tidaknya hubungan di antara variabel-variabel penelitian berdasarkan besarkecilnya koefisien korelasi. Tekhnik pengumpulan data menggunakan tekhnik survei dengan melalui penyebaran angket (kuesioner), EFT, dan tes hasil belajar. Penelitian dilakukan dengan menyebarkan ketiga instrumen pada kelas yang dijadikan sampel penelitian. Angket/kuesioner diberikan untuk mengetahui sikap siswa dan gaya belajar siswa terhadap kemampuan menulis deskriptif bahasa Inggris, tes gaya belajar model H.Witkin atau Embedded Figure Test (EFT) digunakan untuk memetakan gaya belajar independen dan atau tidak independen gaya belajar yang dimiliki siswa (Ronald R, and $\mathrm{J}$. Sims, 1995: 36), sedangkan tes digunakan untuk mengukur hasil belajar yang mengukur kemampuan menulis deskriptif bahasa Inggris.

Kegiatan penelitian ini dilakukan pada siswa kelas XI SMA Negeri 2 Kambowa di wilayah Kabupaten 
Buton Utara pada tahun 2016/2017. Pelaksanaan penelitian dilaksanakan mulai Mei 2016 sampai dengan Februari 2017.

Adapun yang menjadi populasi dalam penelitian adalah seluruh siswa kelas XI pada SMA Negeri 2 Kambowa. Sedangkan pengambilan sampel dalam penelitian ini menggunakan purposive sampling yaitu penetapan sampel sesuai dengan variabel penelitian yang dilakukan yang mana sampel target yang diinginkan adalah sampel yang diambil guna mengukur kemampuan menulis deskriptif bahasa Inggris dan dilakukan secara acak (random sampling), dari pengambilan sampel diperoleh sampel sebesar 30 .

Data yang diperoleh dari hasil penelitian dianalisis dengan menggunakan analisis statistik deskriptif dan analisis statistik inferensial. Analisis statistik deskriptif dilakukan dengan mendeskripsikan semua data dari semua variabel dalam bentuk; distribusi frekuensi, histogram, modus, median, total skor, harga rata-rata (mean), simpangan baku (standar deviasi), dan varians. Sedangkan analisis statistik inferensial dilakukan untuk menguji hipotesis yang telah dirumuskan. Tekhnik pengujian menggunakan statistik uji-t dan uji-F untuk menguji koefisien korelasi product moment sederhana dan korelasi berganda.

\section{HASIL DAN PEMBAHASAN \\ Hasil Kemampuan Menulis Deskriptif Bahasa Inggris}

Hasil penelitian memberikan gambaran bahwa rentangan skor hasil kemampuan menulis deskriptif bahasa Inggris sampel berada pada skor minimum sebesar 35 sampai dengan skor maksimum 95 dengan skor maksimum teoretis sebuah hasil kemampuan menulis yang sangat baik yaitu skor 100. Keseluruhan skor yang diperoleh seluruh sampel sebesar 2045; dengan nilai rata-rata (mean) atas hasil belajar pada tes kemampuan menulis sebesar 68,17 artinya kemampuan menulis deskriptif bahasa Inggris rata-rata sampel berada pada tingkat kemampuan yang cukup. Standar deviasi atau derajat penyimpangan atas nilai hasil kemampuan menulis deskriptif bahasa Inggris hanya sebesar 14,55; modus atau nilai kemampuan yang sering muncul yang ditunjukkan sampel dalam kemampuan menulis deskriptif bahasa Inggris sebesar 64,25; skor median atau nilai tengah yang ditunjukkan sampel dalam kemampuan menulis deskriptif bahasa Inggris sebesar 66,5 dan nilai varians sebesar 324,047. Dari data penelitian dapat dibuat daftar distribusi frekuensi sebagaimana yang terlihat pada tabel 1 .

Tabel 1. Distribusi Frekuensi Deskriptif Bahasa Inggris 
BAHTERA: Jurnal Pendidikan Bahasa dan Sastra, Volume 16 Nomor 2 Juli 2017 http://journal.unj.ac.id/unj/index.php/bahtera/

\begin{tabular}{cccc}
\hline No & Kelas Interval & Frek. Absolut & Frek.Realtif \\
\hline 1 & $26-35$ & 1 & 3,33 \\
2 & $36-45$ & 0 & 0 \\
3 & $46-55$ & 3 & 10 \\
4 & $56-65$ & 10 & 33,33 \\
5 & $66-75$ & 9 & 30 \\
6 & $76-85$ & 1 & 3,33 \\
7 & $86-95$ & 6 & 20 \\
\hline Jumlah & & $\mathbf{3 0}$ & $\mathbf{1 0 0 \%}$
\end{tabular}

Berdasarkan data yang dapat terlihat pada tabel 1, diperoleh informasi bahwa sebanyak 14 orang atau $46,67 \%$ berada di bawah skor rata-rata, 9 orang atau $30 \%$ berada pada skor rata-rata, dan 7 orang atau $23,33 \%$ berada di atas skor rata-rata.

Selanjutnya, jika data tersebut dibandingkan dengan nilai maksimum teoretis atas analisis kemampuan menulis deskriptif bahasa Inggris pada level yang sangat baik yaitu sebesar 100 dengan skor median teoretis 50, maka diperoleh informasi bahwa kemampuan menulis deskriptif bahasa Inggris siswa kelas XI SMA Negeri 2 kambowa di wilayah kabupaten Buton Utara Sulawesi Tenggara berada dalam kategori yang cukup.
Uraian ini memberikan gambaran bahwa hasil kemampuan menulis deskriptif bahasa Inggris di SMA Negeri 2 Kambowa di kabupaten Buton Utara Sulawasi Tenggara berada pada level yang cukup. Hal ini menunjukkan bahwa kualitas pembelajaran bahasa Inggris khususnya kemampuan menulis deskriptif bahasa Inggris dilihat dari segi output termasuk berada dalam kategori cukup. Peningkatan kualitas pembelajaran bahasa Inggris dapat dilakukan dengan meningkatkan kompetensi guru dan peningkatan sarana dan prasarana pembelajaran.

Adapun grafik histogram dari sebaran data skor kemampuan menulis deskriptif bahasa Inggris dapat dilihat pada gambar berikut:

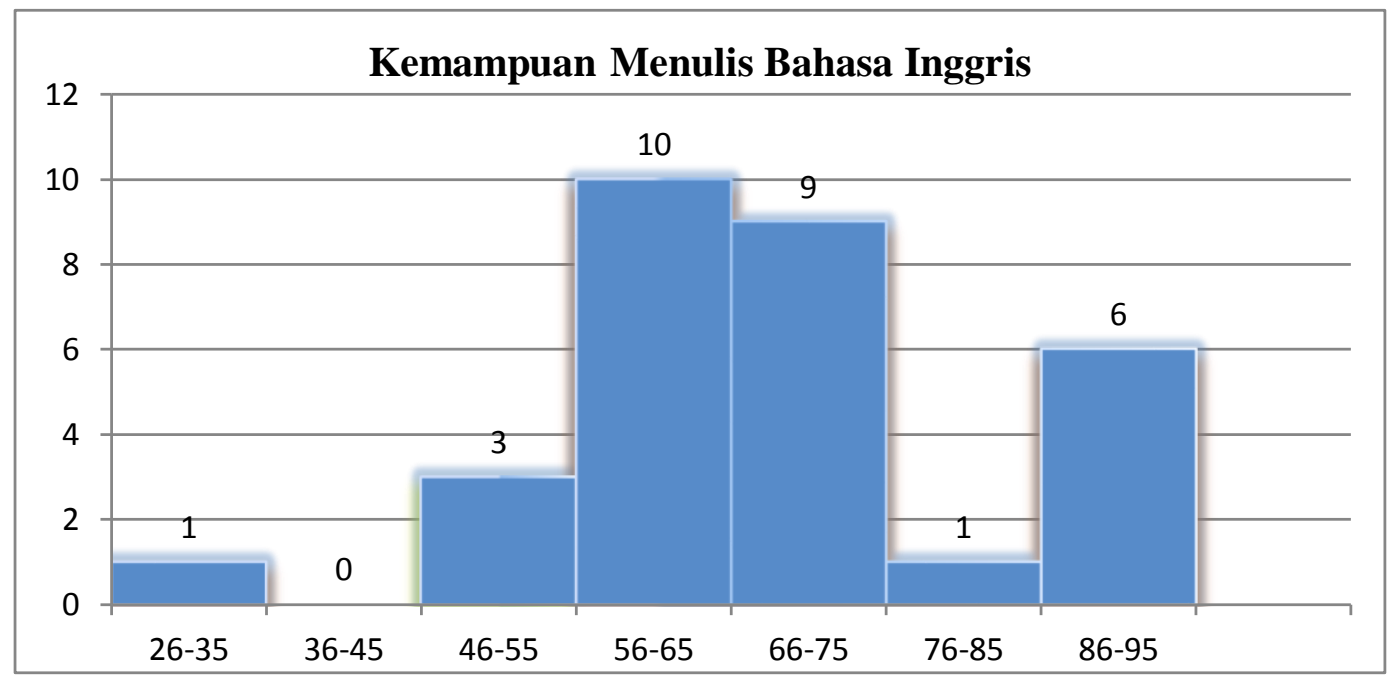




\section{Hasil Sikap Siswa Terhadap Kemampuan Menulis Deskriptif Bahasa Inggris}

Hasil penelitian memberikan gambaran bahwa rentangan skor hasil sikap siswa terhadap kemampuan menulis deskriptif bahasa Inggris berada pada skor minimum sebesar 97 sampai dengan skor maksimum 169 dengan skor maksimum teoretis sebuah hasil analisis teori sikap siswa tehadap kemampuan menulis deskriptif bahasa Inggris pada level yang sangat baik yaitu sebesar 172 . Keseluruhan skor yang diperoleh seluruh sampel atas respon pada sikap terhadap kemampuan menulis deskriptif bahasa Inggris sebesar
3873; dengan nilai rata-rata (mean) atas sikap siswa yang ditunjukkan terhadap kemampuan menulis deskriptif bahasa Inggris sebesar 129,1 , standar deviasi atau derajat penyimpangan sikap siswa terhadap kemampuan menulis deskriptif bahasa Inggris hanya sebesar 17,75, nilai yang sering muncul atau modus pada sikap siswa terhadap kemampuan menulis deskriptif bahasa Inggris sebesar 128,884; skor median atau nilai tengah dari sikap siswa terhadap kemampuan menulis deskriptif bahasa Inggris sebesar 129,14 dan nilai varians sebesar 275,651. Dari data penelitian dapat dibuat daftar distribusi frekuensi sebagaimana yang terlihat pada tabel 2

Tabel 2. Distribusi Frekuensi Hasil Sikap Siswa Terhadap Kemampuan Menulis Deskriptif Bahasa Inggris

\begin{tabular}{cccc}
\hline No & Kelas Interval & Frek.Absolut & Frek.Realtif \\
\hline 1 & $86-97$ & 1 & $3,33 \%$ \\
2 & $98-109$ & 4 & $13,33 \%$ \\
3 & $110-121$ & 3 & $10 \%$ \\
4 & $122-133$ & 11 & $36,67 \%$ \\
5 & $134-145$ & 6 & $20 \%$ \\
6 & $146-157$ & 3 & $10 \%$ \\
7 & $158-169$ & 2 & $6,67 \%$ \\
\hline Jumlah & & $\mathbf{3 0}$ & $\mathbf{1 0 0 \%}$ \\
\hline
\end{tabular}

Berdasarkan data yang dapat terlihat pada tabel 2, diperoleh informasi bahwa sebanyak 11 orang atau sebesar $36,67 \%$ berada pada skor rata-rata dan di atas skor ratarata, dan 8 orang lainnya atau $26,67 \%$ berada di bawah skor ratarata.

Selanjutnya, jika data tersebut dibandingkan dengan skor maksimum teoritis sebesar 172 dan memiliki nilai median teoretis 86, maka dapat disimpulkan bahwa hasil sikap siswa terhadap kemampuan menulis deskriptif bahasa Inggris siswa kelas XI SMA Negeri 2 kambowa di wilayah kabupaten Buton Utara Sulawesi Tenggara termasuk dalam kategori tinggi atau positif. 
Sikap positif siswa terhadap hasil kemampuan menulis deskriptif bahasa Inggris di SMA Negeri 2 Kambowa Sulawesi Tenggara ini merupakan salah satu reaksi dari baiknya kualitas proses pembelajaran bahasa Inggris itu sendiri. Sikap positif ini menggambarkan kesukaan atau kesenangan (like) siswa terhadap pembelajaran menulis deskriptif bahasa Inggris.

Adapun grafik histogram dari sebaran data skor sikap siswa terhadap kemampuan menulis deskriptif bahasa Inggris dapat dilihat pada gambar berikut:

\section{Hasil Gaya Belajar Siswa Terhadap Kemampuan Menulis Deskriptif Bahasa Inggris}

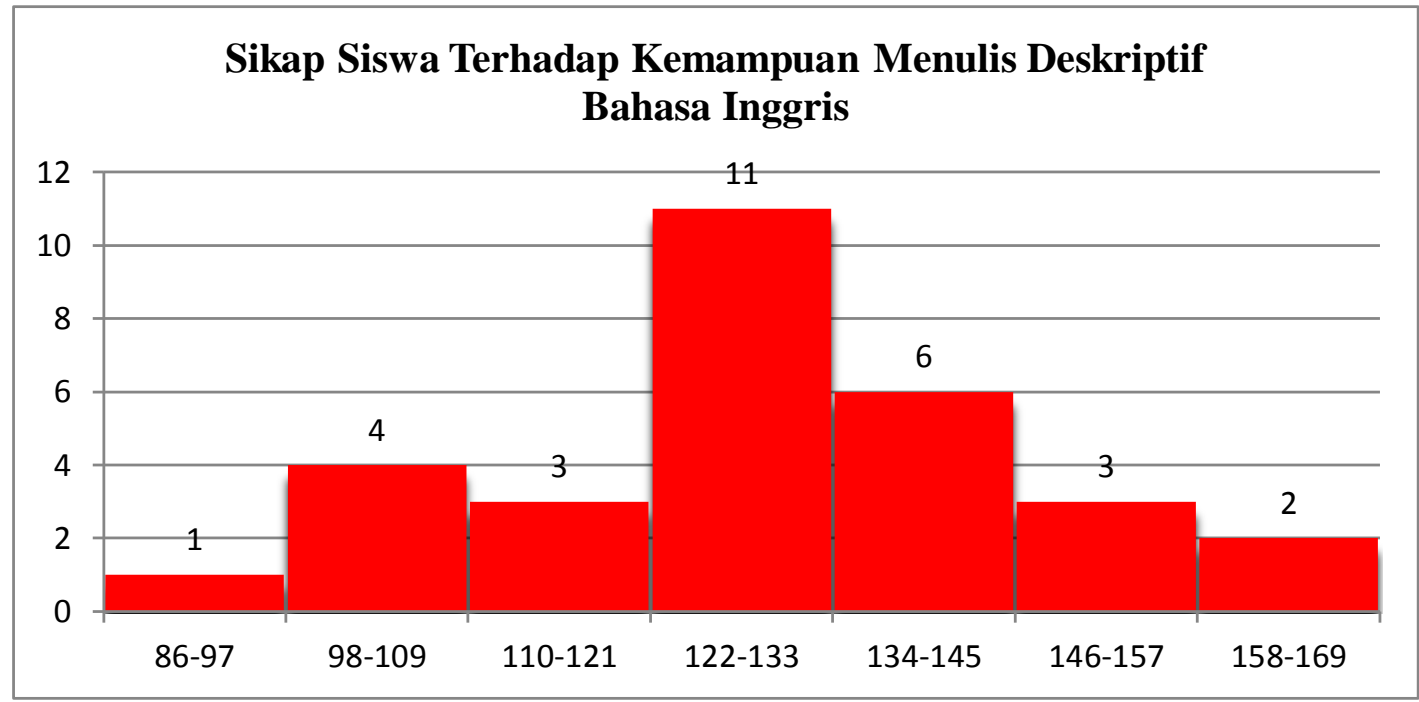

Hasil penelitian memberikan gambaran bahwa rentangan skor hasil gaya belajar siswa terhadap kemampuan menulis deskriptif bahasa Inggris berada pada skor minimum sebesar 30 sampai dengan skor tertinggi sebesar 102. Adapun untuk skor maksimum yang harusnya diperoleh siswa berdasarkan kajian teoretis untuk gaya belajar sebanyak 104. Berdasarkan kuesioner yang diberikan skor total seluruh siswa sebesar 1845; dengan nilai rata-rata (mean) sebesar 61,5; standar deviasi sebesar 12,24; modus sebesar 60,282; skor median sebesar 60,588; dan nilai varians sebesar 149,793 . Dari data penelitian dapat dibuat daftar distribusi frekuensi sebagaimana yang terlihat pada tabel 3. 
BAHTERA: Jurnal Pendidikan Bahasa dan Sastra, Volume 16 Nomor 2 Juli 2017 http://journal.unj.ac.id/unj/index.php/bahtera/

Tabel 3. Distribusi Frekuensi Hasil Gaya Belajar Siswa Terhadap Kemampuan Menulis Deskriptif Bahasa Inggris

\begin{tabular}{cccc}
\hline No & Kelas Interval & Frek.Absolut & Frek.Realtif \\
\hline 1 & $30-41$ & 1 & $3,33 \%$ \\
2 & $42-53$ & 4 & $13,33 \%$ \\
3 & $54-65$ & 17 & $56,67 \%$ \\
4 & $66-77$ & 7 & $23,33 \%$ \\
5 & $78-89$ & 0 & $0 \%$ \\
6 & $90-101$ & 0 & $0 \%$ \\
7 & $102-113$ & 1 & $3,3 \%$ \\
\hline Jumlah & & $\mathbf{3 0}$ & $\mathbf{1 0 0 \%}$ \\
\hline
\end{tabular}

Berdasarkan data yang dapat terlihat pada tabel 3, diperoleh informasi bahwa sebanyak 17 orang atau $56,67 \%$ berada pada skor ratarata, 8 orang atau $26,67 \%$ berada di atas skor rata-rata, dan 5 orang atau $16,67 \%$ berada di bawah skor ratarata.

Selanjutnya, jika data tersebut dibandingkan dengan skor maksimum teoritis sebesar 104 dan memiliki nilai median teoretis 52, diperoleh informasi bahwa hasil kuesioner tentang gaya belajar siswa terhadap kemampuan menulis deskriptif bahasa Inggris siswa kelas XI SMA Negeri 2 kambowa di wilayah kabupaten Buton Utara Sulawesi Tenggara termasuk dalam kategori dengan nilai yang tinggi.

Sedangkan berdasarkan pemetaan gaya belajar siswa, berdasarkan tes pemetaan gaya belajar model $\mathrm{H}$. Witkin (Embedded Figure Test) yang diberikan, dari rentang waktu yang diberikan selama 5 menit untuk mengidentifikasi figur-figur sederhana yang tersembunyi dalam keseluruhan figur gambar yang kompleks yang diberikan, dari tes EFT tersebut, 30 sampel terindikasi memiliki gaya belajar yang field independent, ini didasarkan pada keseluruhan sampel yang mampu mengidentifikasikan gambar-gambar kecil yang tersembunyi dalam pola gambar yang besar.

Uraian ini memberikan gambaran bahwa hasil kuesioner gaya belajar siswa terhadap kemampuan menulis deskriptif bahasa Inggris di SMA Negeri 2 Kambowa di kabupaten Buton Utara Sulawasi Tenggara berada pada kategori dengaan nilai yang tinggi dan terindikasi memiliki gaya belajar yang independen. Gaya belajar siswa terhadap hasil kemampuan menulis deskriptif bahasa Inggris di SMA Negeri 2 Kambowa Sulawesi Tenggara ini merupakan salah satu reaksi dari baiknya proses pemahaman karakter siswa dalam mengenali gaya belajar yang dimiliki sehingga mendapatkan hasil pembelajaran khususnya kemampuan menulis deskriptif bahasa Inggris dengan kategori kualitas yang baik.

Adapun grafik histogram dari sebaran data skor gaya belajar siswa terhadap kemampuan menulis 
deskriptif bahasa Inggris dibuat dapat

dilihat pada gambar berikut:

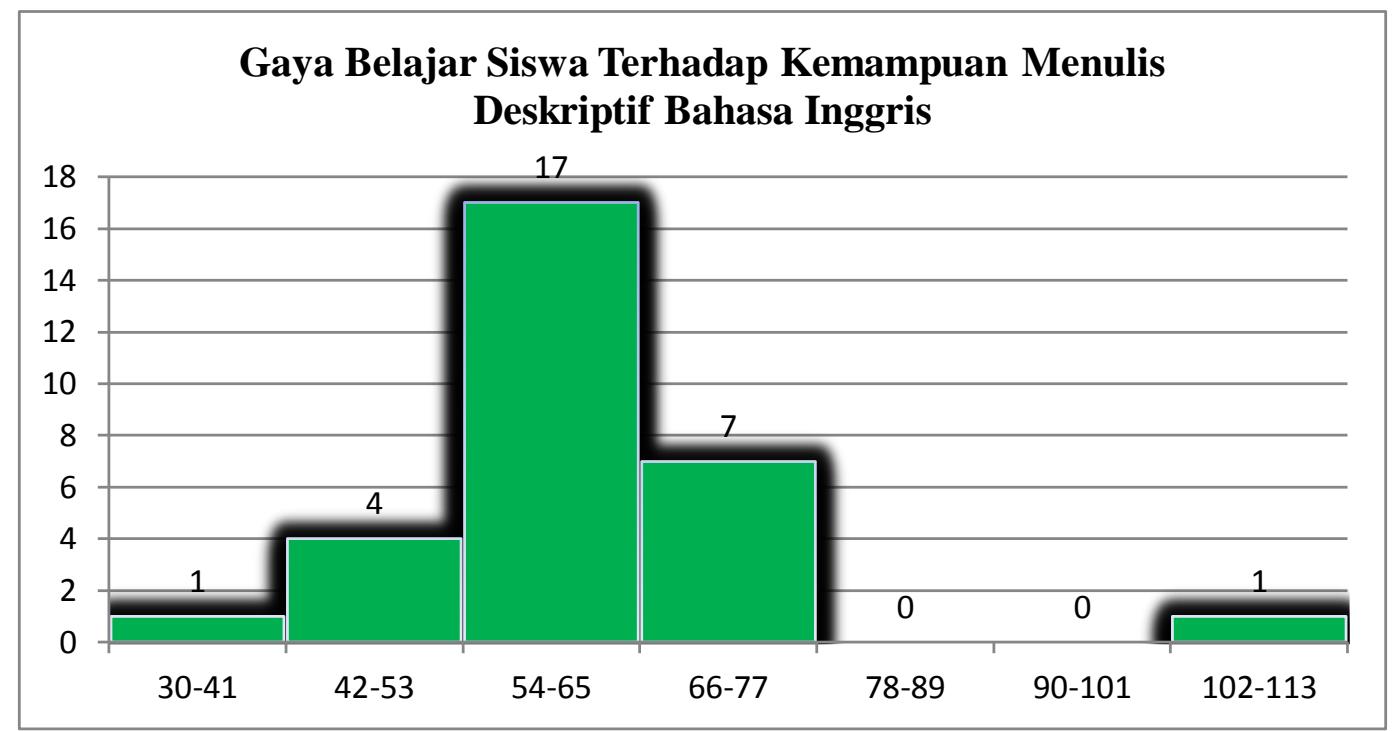

\section{Pengujian Hipotesis Dan Pembahasan}

Sebelum dilakukan pengujian hipotesis terlebih dahulu diadakan uji prasyarat , yakni pengujian normalitas, homogenitas, dan linearitas data. Pengujian normalitas dilakukan untuk mengetahui normal tidaknya suatu distribusi data. Hasil uji normalitas data dengan melihat galat taksiran tiap variabel dengan menggunakan Uji liliefors, penggunaan dengan Uji liliefors dilakukan apabila data merupakan data tunggal atau data frekuensi tunggal, bukan data distribusi frekuensi kelompok. Pengujian homogenitas dilakukan dalam rangka menguji kesamaan varians setiap kelompok data. Uji homogenitas dilakukan dengan uji F-Fisher, penggunaan Uji $F$ (Fisher) dapat dilakukan apabila data yang akan diuji hanya ada 2 (dua) kelompok data/sampel. Sedangkan uji linearitas data dilakukan dengan uji baris linearity, ini dilakukan dalam rangka menguji model persamaan regresi suatu variabel $\mathrm{Y}$ atas suatu variabel $\mathrm{X}$. Hasil uji normalitas dapat dilihat pada tabel 4.

Tabel 4. Ringkasan Hasil pengujian Normalitas

\begin{tabular}{|c|c|c|c|c|c|c|}
\hline \multirow[b]{2}{*}{ Galat Taksiran Regresi } & \multirow{2}{*}{$\mathbf{N}$} & \multirow{2}{*}{ Lhitung } & \multicolumn{2}{|c|}{$\mathbf{L}_{\text {tabel }}$} & \multirow{2}{*}{ Kriteria } & \multirow{2}{*}{ Keterangan } \\
\hline & & & $\alpha=0,05$ & $\alpha=\mathbf{0 , 0 1}$ & & \\
\hline$\hat{\mathrm{Y}} \operatorname{atas} \mathrm{X}_{1}$ & 30 & 0,155 & 0,161 & 0,187 & $\mathrm{~L}_{\text {hitung }}<\mathrm{L}_{\text {tabel }}$ & Normal \\
\hline$\hat{\mathrm{Y}} \operatorname{atas} \mathrm{X}_{2}$ & 30 & 0,116 & 0,161 & 0,187 & $\mathrm{~L}_{\text {hitung }}<\mathrm{L}_{\text {tabel }}$ & Normal \\
\hline$\hat{\mathrm{Y}}$ atas atas $\mathrm{X}_{1}$ dan $\mathrm{X}_{2}$ & 30 & 0,155 & 0,161 & 0,187 & $\mathrm{~L}_{\text {hitung }}<\mathrm{L}_{\text {tabel }}$ & Normal \\
\hline
\end{tabular}

Berdasarkan tabel 4. Tersebut semua nilai $L_{\text {hitung baik untuk } \hat{Y} \text { atas }}$ $\mathrm{X}_{1}, \mathrm{X}_{2}$, maupun secara bersama-sama $\mathrm{X}_{1}, \mathrm{X}_{2}$ terhadap $\hat{\mathrm{Y}}$ lebih kecil dari nilai $\mathrm{L}_{\text {tabel }}$ dengan $\alpha=0,05$. Maka dapat disimpulkan bahwa data sampel berdistribusi secara normal. 
Sedangkan hasil uji homogenitas

berikut: dapat dilihat pada tabel 5 sebagai

Tabel 5. Ringkasan Hasil Pengujian Homogenitas

\begin{tabular}{ccccccc}
\hline $\begin{array}{c}\text { Kelompok } \\
\text { Varians }\end{array}$ & $D_{\mathrm{k}}$ & $\mathrm{F}_{\text {hitung }}$ & \multicolumn{2}{c}{$\mathrm{F}_{\text {tabel }}$} & \multirow{2}{*}{ Kriteria } & \multirow{2}{*}{ Simpulan } \\
\hline $\mathrm{X}_{1}$ & 6 & 2,163 & \multirow{2}{*}{4,28} & 8,47 & $\mathrm{~F}_{\text {hitung }}<\mathrm{F}_{\text {tabel }}$ & Homogen \\
$\mathrm{X}_{2}$ & 6 & 2,163 & & & $\mathrm{~F}_{\text {hitung }}<\mathrm{F}_{\text {tabel }}$ & Homogen \\
\hline
\end{tabular}

Berdasarkan tabel 5. Tersebut semua nilai $F_{\text {hitung }}$ baik untuk kelompok varians atas $\mathrm{X}_{1}$, dan $\mathrm{X}_{2}$, lebih kecil dari nilai $\mathrm{F}_{\text {tabel }}$ dengan $\alpha=$ 0,05 . Maka dapat disimpulkan bahwa data sampel berdistribusi secara Homogen. Adapun hasil pengujian linearitas dapat terlihat pada tabel 6 . Di bawah ini:

Tabel 6. Ringkasan Hasil Pengujian Linearitas

\begin{tabular}{|c|c|c|c|c|c|c|}
\hline \multirow[b]{2}{*}{ Reg. } & \multirow[b]{2}{*}{ Persamaan } & \multicolumn{2}{|c|}{ Uji Regresi } & \multicolumn{2}{|c|}{ Uji Linearitas } & \multirow[b]{2}{*}{ Simpulan } \\
\hline & & $F_{\text {hitung }}$ & $\begin{array}{c}F_{\text {tabel }} \\
\alpha=0,05\end{array}$ & $F_{\text {hitung }}$ & $\begin{array}{c}\mathrm{F}_{\text {tabel }} \\
\alpha=0,05\end{array}$ & \\
\hline $\mathrm{Y}$ atas $\mathrm{X}_{1}$ & $\hat{\mathbf{Y}}=\mathbf{- 3 8 , 5 4}+\mathbf{0 , 8 2 6} \mathrm{X}_{1}$ & 262,85 & 4,17 & $-0,22^{\mathrm{ns}}$ & 4,53 & $\begin{array}{c}\text { Regresi sangat } \\
\text { signifikan/regresi } \\
\text { linear }\end{array}$ \\
\hline $\mathrm{Y} \operatorname{atas} \mathrm{X}_{2}$ & $\hat{\mathbf{Y}}=4,387+1,043 \mathrm{X}_{2}$ & $83,99 * *$ & 4,17 & $-0,58^{\mathrm{ns}}$ & 2,77 & $\begin{array}{c}\text { Regresi sangat } \\
\text { signifikan/regresi } \\
\text { linear }\end{array}$ \\
\hline $\begin{array}{l}Y \operatorname{atas} \mathrm{X}_{1} \\
\operatorname{dan} \mathrm{X}_{2}\end{array}$ & $\begin{array}{c}\hat{Y}=- \\
-40,3055+0,874 X_{1} \\
+-0,072 X_{2}\end{array}$ & $127,828 * *$ & 3,32 & - & - & $\begin{array}{l}\text { Regresi sangat } \\
\text { signifikan }\end{array}$ \\
\hline
\end{tabular}

Berdasarkan tabel 6. Tersebut, semua nilai untuk Uji Regresi dan Linearitas diperoleh $F_{\text {hitung baik untuk }}$ $\hat{Y}$ atas $X_{1}, X_{2}$, maupun secara bersama-sama $X_{1}, X_{2}$ terhadap $\hat{Y}$ lebih kecil dari nilai $\mathrm{F}_{\text {tabel }}$ dengan $\alpha=$ 0,05 . Maka dapat disimpulkan bahwa data sampel berdistribusi secara signifikan dan memiliki regresi yang linear.

Setelah melakukan uji persyarat dan memenuhi persyaratan. Maka, dapat dilakukan pengujian hipotesis, hasil pengujian dapat terlihat pada tabel 7. Berikut ini:

Tabel 7. Ringkasan Hasil Pengujian Hipotesis

\begin{tabular}{ccccccccc}
\hline Hipotesis & $\begin{array}{c}\text { Variabel yang } \\
\text { dikorelasikan } \\
\text { dengan variabel } \\
\mathrm{Y}\end{array}$ & $\begin{array}{c}\text { Koefisien } \\
\text { Korelasi }\end{array}$ & $\begin{array}{c}\text { Statistik } \\
\text { Uji t- } \\
\text { hitung/F } \\
\text {-Hitung }\end{array}$ & $\begin{array}{c}\mathrm{t} \text {-Tabel } / \\
\mathrm{t} \text {-Tabel }\end{array}$ & $\begin{array}{c}\text { Nilai } \\
\text { Sig. }\end{array}$ & Nilai Sig. & $\begin{array}{c}\text { Stiteria } \\
\text { Uji }\end{array}$ & $\begin{array}{c}\text { Ket.Hasil } \\
\text { Pengujian }\end{array}$ \\
\hline $\mathrm{H}_{1}$ & $\mathrm{X}_{1}$ & 0,95 & 16,09 & 2,048 & 0,000 & Sig.<0,05 & $\begin{array}{r}\mathrm{t}_{\text {hitung }}> \\
\mathrm{t}_{\text {tabel }}\end{array}$ & Signifikan \\
\hline
\end{tabular}




$\begin{array}{lcccccccc}\mathrm{H}_{2} & \mathrm{X}_{2} & 0,87 & 9,164 & 2,048 & 0,000 & \text { Sig.<0,05 } & \begin{array}{c}\mathrm{t}_{\text {hitung }}> \\ \mathrm{t}_{\text {tabel }}\end{array} & \text { Signifikan } \\ \mathrm{H}_{3} & \mathrm{X}_{1}, \mathrm{X}_{2} & 0,95 & 124,930 & 2,052 & 0,000 & \text { Sig. }<0,05 & \begin{array}{c}\mathrm{t}_{\text {hitung }}> \\ \mathrm{t}_{\text {tabel }}\end{array} & \text { Signifikan }\end{array}$

\section{Hubungan Antara Sikap Siswa Terhadap Kemampuan Menulis Deskriptif Bahasa Inggris}

Hasil pengujian hipotesis pertama menunjukan bahwa terdapat hubungan yang signifikan antara sikap siswa terhadap kemampuan menulis deskriptif bahasa Inggris dengan nilai koefisien korelasi sebesar 0,95 dengan sig.(1-tailed) $=0,000$. Oleh karena nilai sig. ini < 0,05 , sehingga $\mathrm{H}_{0}$ ditolak dengan kata lain hipotesis alternative diterima. Hasil ini juga dengan melihat $t_{\text {hitung }}>\mathrm{t}_{\text {tabel }} 16,09>2,048$. Berdasarkan hasil ini dapat disimpulkan bahwa terdapat hubungan yang positif dan signifikan antara $\mathrm{X}_{1}$ dengan $\mathrm{Y}$ dengan koefisien korelasi sebesar 0,95.

Hasil penelitian ini sejalan dengan kajian tentang sikap. Menurut Herlen, sikap merupakan kesiapan atau kecenderungan seseorang untuk bertindak dalam menghadapi suatu objek atau situasi tertentu (Djaali, 2008:114). Menurut Slameto (2010:188-189), sikap selalu berkaitan dengan dengan suatu objek, adapun kaitan antara sikap dengan objek tersebut ditunjukkan dengan perasaa yang positif ataupun negatif, seseorang memiliki sikap positif terhadap suatu objek yang dianggap bernilai, dan hal sebaliknya perasaan negatif akan muncul ketika objek tersebut tidak bernilai dalam pandangannya, kemudian sikap ini mendorong dan mendasari kepada beberapa kegiatan yang saling terhubung satu sama lainnya.

Pada pembahasan yang sama, Slameto mengatakan bahwa faktor lain yang mempengaruhi hasil belajar siswa adalah sikap (Slameto, 2010:188). Sikap ditunjukkan seseorang ketika menghadapi sesuatu. Julian (1993:26). memaparkan bahwa jika seseorang memiliki sikap positif terhadap suatu bahasa maka hal tersebut akan membantu memudahkan dalam mempelajari bahasa tersebut. Oleh karena itu, sikap dapat dianggap sebagai suatu kecenderungan untuk memberikan respon terhadap objek yang diterima, berdasarkan informasi awal terkait dengan obyek tersebut, yang diwujudkan dengan konsep berpikir yang positif atau negatif, perasaan senang atau tidak senang dan diwujudkan dengan tindakan nyata terhadap objek tersebut.

Sedangkan, kemampuan menulis deskriptif adalah sebuah tujuan yang diharapkan dapat diperoleh setiap siswa dalam mempelajari satu objek mata pelajaran tertentu, yang diharapkan memberikan manfaat. Sehingga, siswa dapat mengeskpresikan atau menggambarkan sesuatu objek baik berupa orang, tempat, atau suasana yang diindrawikannya yang tertuang dalam bentuk tulisan, yang memberikan gambaran seolah-olah tulisan tersebut dapat hidup atau terlihat, teraba, dirasakan, atau 
terbaui seperti apa yang dialami penulis.

Berdasarkan paparan di atas diperoeh informasi bahwa sikap terhadap kemampuan menulis deskriptif bahasa Inggris adalah kecenderungan siswa memberikan respon terhadap mata pelajaran bahasa Inggris, terutama aspek menulis deskriptif, respon yang ditunjukkan mencakup konsep berpikir positif atau negatif, perasaan senang atau tidak senang dan tindakan nyata yang dilakukan terhadap mata pelajaran bahasa Inggris, khususnya pada menulis deskriptif bahasa Inggris. Berdasarkan hasil penelitian ini terbukti bahwa semakin baik atau positif sikap yang ditunjukkan siswa maka akan semakin baik kemampuan menulis deskriptif bahasa Inggrisnya.

\section{Hubungan Antara Gaya Belajar Siswa Terhadap Kemampuan Menulis Deskriptif Bahasa Inggris}

Hasil pengujian hipotesis kedua menunjukan bahwa terdapat hubungan yang signifikan antara gaya belajar siswa terhadap kemampuan menulis deskriptif bahasa Inggris dengan nilai koefisien korelasi sebesar 0,87 dengan sig.( 1 tailed) $=0,000$. Oleh karena nilai sig.ini $<0,05$, sehingga $\mathrm{H}_{0}$ ditolak dengan kata lain hipotesis alternatif diterima. Hasil ini juga dengan melihat $t_{\text {hitung }}>\mathrm{t}_{\text {tabel }} 9,164>2,048$. Berdasarkan hasil ini dapat disimpulkan bahwa terdapat hubungan yang positif dan signifikan antara $\mathrm{X}_{2}$ dengan $\mathrm{Y}$ dengan koefisien korelasi sebesar 0,87
Secara teoretis, gaya belajar jika dihubungkan dengan prestasi hasil belajar khususnya kemampuan menulis deskriptif bahasa Inggris dapat dicapai dengan baik. Mengingat peningkatan prestasi belajar dicapai dengan memperhatikan beberapa aspek, baik internal maupun eksternal. Aspek eksternal di antaranya adalah bagaimana lingkungan belajar dipersiapkan dan fasilitas-fasilitas diberdayakan, sedangkan aspek internal meliputi aspek perkembangan anak dan keunikan personal individu anak. Dalam hal ini setiap anak memiliki cara pandang tersendiri dalam melihat setiap peristiwa dan dialami cara pandangan ini yang kemudian disebut dengan gaya belajar (Ghufron \& Risnawita, 2014: 10).

Konsep hubungan gaya belajar dengan prestasi belajar salah satunya kemampuan menulis deskriptif bahasa Inggris di atas didukung pada hasil penelitian Marton dkk memberikan simpulan bahwa kemampuan seseorang untuk mengetahui sendiri gaya belajarnya dan gaya belajar orang lain dalam lingkungannya akan meningkatkan efektifitas belajarnya (Ghufron \& Risnawita, 2014: 12).

Ahli lain Dunn mengatakan dari beberapa tinjauan pustaka menunjukkan adanya bukti telah terjadi satu kebangkitan kembali yang membahasa mengenai gaya belajar untuk menemukan gaya belajar berpengaruh terhadap proses belajar individu (Dunn dalam Ghufron \& Risnawita, 2014: 41) 


\section{Hubungan Antara Sikap Siswa dan Gaya Belajar Siswa Terhadap Kemampuan Menulis Deskriptif Bahasa Inggris}

Hasil pengujian hipotesis ketiga menunjukan bahwa, terdapat hubungan yang signifikan antara sikap dan gaya belajar siswa secara bersama-sama terhadap kemampuan menulis deskriptif bahasa Inggris dengan nilai koefisien korelasi sebesar 0,95 dengan sig.(2-tailed) $=0,000$. Oleh karena nilai sig.ini < 0,05, sehingga $\mathrm{H}_{0}$ ditolak dengan kata lain hipotesis alternatif diterima. Hasil ini juga dengan melihat $\mathrm{t}_{\text {hitung }}>$ $t_{\text {tabel }} 124,930>2,048$. dengan Berdasarkan hasil ini dapat disimpulkan bahwa terdapat hubungan yang positif dan signifikan antara $\mathrm{X}_{1}$, dan $\mathrm{X}_{2}$ dengan $\mathrm{Y}$ dengan koefisien korelasi sebesar 0,95.

Sikap adalah kecenderungan siswa memberikan respon terhadap obyek yang diterima. Respon yang ditunjukkan mencakup konsep berpikir positif atau negatif, perasaan senang atau tidak senang dan tindakan nyata yang dilakukan terhadap obyek tersebut (Slameto,2010:188-189). Sedangkan, gaya belajar adalah suatu kecenderungan yang konsisten dari seseorang yang ditunjukkan dengan cara yang khusus, yang dianggap paling efektif yang pada umumnya ditentukan lewat cara kita mencerap dan mengatur informasi berkisar dari yang konkret (yang berakar pada panca indra ragawi, menekankan apa yang dapat diamati) hingga yang abstrak (yang berakar dalam emosi dan intuisi, menekankan perasaan dan ide-ide), yang dilakukan seseorang yang berbeda dengan lainnya (Douglas Brown, 2008:127.) yang berorientasi pada keberhasilan dalam suatu hasil pembelajaran atau tindakan pada masa depan. (Glover \& Sue Law, 2005: 89.)

Dengan demikian, sikap sebagai kecenderungan berpikir, perasaan dan tindakan seseorang yang akan diwujudkan dalam satu orientasi keberhasilan dalam satu objek pembelajaran, yang dihadapi dengan menunjukkan kata-kata atau perbuatan yang positif, bersinergi baik dengan gaya belajar sebagai suatu kecenderungan yang konsisten dari seseorang, yang ditunjukkan dengan cara yang khusus yang dianggap paling efektif yang berbeda dengan orang lain, dalam orientasi yang sama yaitu kesuksesan dalam suatu objek yang dihadapi.

Berdasarkan konsep yang diajukan ini, bahwa sikap dan gaya belajar siswa yang cenderung baik dan positif terdapat hubungan yang positif dan baik pula dalam kesuksesan tujuan pembelajaran yang diharapkan yaitu kemampuan menulis deksriptif bahasa Inggris. Dari hasil penelitian terbukti bahwa sikap siswa dan gaya belajar $\left(\mathrm{X}_{1}, \mathrm{X}_{2}\right)$ terbukti secara bersama-sama memiliki hubungan yang positif dan signifikan dengan kemampuan menulis deskriptif bahasa Inggris.

\section{SIMPULAN}

Berdasarkan hasil pengujian hipotesis, tiga hipotesis yang diajukan secara signifikan dapat diterima. Hipotesis pertama yaitu terdapat hubungan yang positif antara sikap siswa terhadap kemampuan menulis deskriptif bahasa Inggris, hipotesis kedua 
terdapat hubungan yang positif antara gaya belajar siswa terhadap kemampuan menulis deskriptif bahasa Inggris, dan hipotesis ketiga terdapat hubungan yang positif antara sikap siswa dan gaya belajar siswa terhadap kemampuan menulis deskriptif bahasa Inggris. Dengan demikian, dapat disimpulkan: pertama, terdapat hubungan yang positif dan signifikan antara sikap siswa terhadap kemampuan menulis deskriptif bahasa Inggris pada SMA Negeri 2 Kambowa di Kabupaten Buton Utara pada tahun 2016/2017 dengan nilai koefisien korelasi sebesar 0,95. Kedua, terdapat hubungan yang positif dan signifikan antara gaya belajar siswa terhadap kemampuan menulis deskriptif bahasa Inggris pada SMA Negeri 2 Kambowa di Kabupaten Buton Utara pada tahun 2016/2017 dengan nilai koefisien korelasi sebesar 0,87. Ketiga, terdapat hubungan yang positif dan signifikan antara sikap dan gaya belajar siswa secara bersama-sama terhadap kemampuan menulis deskriptif bahasa Inggris pada SMA Negeri 2 Kambowa di Kabupaten Buton Utara pada tahun 2016/2017 dengan nilai koefisien korelasi sebesar 0,95.

Dengan demikian, untuk mendapatkan hasil belajar yang baik khususnya dalam pembelajaran menulis deskriptif bahasa Inggris, seorang guru harus mampu memberi, dan mendorong sikap positif siswa dalam pembelajaran dan memberi pemahaman tentang gaya belajar. Sehingga, peserta didik dapat mengoptimalkan diri dan mendapatkan hasil belajar yang baik.

\section{DAFTAR PUSTAKA}

Cahyono, Bambang Yudi, dan Utami Widiati 2011. The Teaching Of English As Foreign Language In Indonesia. Malang: State University of Malang Press.

Djaali. 2008. Psikologi Pendidikan. Jakarta: Bumi Aksara.

Edge, Julian. 1993. Essentials of English Language Teaching. New York: Longman Published.

Ghufron, M. Nur, dan Rini Risnawita, S. 2014. Gaya Belajar; Kajian Teoretik. Yogyakarta: Pustaka Pelajar.

Glover, Derek, dan Sue Law. 2005 Memperbaiki Pembelajaran; Praktik Profesional di Sekolah Menengah, terjemahan Willie Koen. Jakarta: PT. Gramedia.

Leo, Sutanto. 2013. Kiat Jitu Menulis Skripsi, Tesis, dan Disertasi. Jakarta: Erlangga.

Sims, Ronald R, and Serbrenia J. Sims. 1995. The Importance of Learning Style; Understanding The Implication or Learning, Course Design, and Education. London: Greenwood Press.

Slameto. 2010. Belajar dan FaktorFaktor yang Mempengaruhi. Jakarta: Rineka Cipta.

Zahari, Musril. 2011. Menjunjung Bahasa Persatuan. Jakarta: Gria Media Prima.

Tarigan, Henry Guntur. 2008. Menulis Sebagai Suatu Keterampilan berbahasa. Bandung: Angkasa bandung. 